\title{
PLANT GROWTH PROMOTING RHIZOBACTERIA (PGPR) FOR SUSTAINABLE AGRICULTURE
}

\section{RAJANI SRIVASTAVA \& ANSHIKA SINGH}

Environmental Science (Environmental Technology), Institute of Environment and

Sustainable Development, RGSC, Banaras Hindu University, Varanasi, India

\begin{abstract}
As Green revolution' seems to have started slowing down and in some cases crop yields have either remained stagnant or declined, besides causing other environmental health problems. For facilitating nutrient uptake and improving soil organic matter status, Plant Growth Promoting Rhizobacteria (PGPR) technology is widely recognized, offering the use of soil microorganisms in practicing sustainable and climate resilient agriculture, eliminating the use of chemical fertilizers and pesticides. PGPR is also proved to promote the activities of bioremediation and biodegradation of hazardous substances present in soil, air or water. It promotes plant growth and development by using their own metabolism through a variety of direct or indirect mechanism such as biological nitrogen fixation, increasing the availability of nutrients in rhizosphere, enhancing the absorption of iron through siderophore production and production of phytohormones. It also used as bio control agents (bio pesticides) providing resistance against plant pathogens by synthesising a variety of antibiotic and antifungal compounds. Thus, PGPRs can have wide applications in the restoration of waste lands and agricultural lands and can be named as sustainability indicator in terms of agriculture and environment as they are used as bio fertilizers, bio control agents and soil fertility improvers promoting agriculture in eco-friendly manner.
\end{abstract}

KEYWORDS: PGPR, Sustainability Indicator, Bio Fertilizers \& Bio Control Agents

Received: Jun 28, 2017; Accepted: Jul 20, 2017; Published: Jun 29, 2017; Paper Id.: IJASRAUG201765

\section{INTRODUCTION}

Currently, Green revolution' seems to have started slowing down and in some cases crop yields have either remained stagnant or declined, besides causing other environmental health problems. Imbalanced nutrient management and decreased soil organic matter are the main indicators of yield decline. Besides this, climate change also affects the soil microbial biodiversity, physico-chemical properties and nutrient availability of soil. Thus, there is need to develop sustainable, climate resilient and adaptive agricultural practices. Agricultural sustainability is the foremost important part of the sustainable development as it is one of the major sources of negative environmental consequences. Soil microbes are known to play essential role in environmental and agricultural sustainability from the time of their discovery. Soil microbes which are found associated with plants have the capability to be utilised as bio fertilizers to overcome the problems related to soil salinity, fertility, degradation, habitat loss and lowering environmental stress (Glick, 2010). The PGPR technology is one such approach of late 1980s in fields of biotechnology offering the use of soil microorganisms in practicing sustainable and climate resilient agriculture, eliminating the use of chemical fertilizers and pesticides. Rhizospheric microorganisms promoting plant growth promotion activity were classified as Plant Growth Promoting Rhizobacteria(PGPR). PGPR is basically root colonizing bacteria that have multifunctional role as it exert 
beneficial effects on plant growth and development and soil health. Besides that, PGPR is also proved to promote the activities of bioremediation and biodegradation of hazardous substances present in soil, air or water (such as heavy metals, organic pollutants, etc).

\section{TYPES OF PGPR}

Plant Growth Promoting Rhizobacteria are the soil microbes found in the atmosphere around the plant's root known as rhizosphere. There are basically two groups of Rhizobacteria; endophytic (symbiotic) and ectophytic (nonsymbiotic) or rhizospheric. Rhizobacteria such as Bacillus, Pseudomonas, Serratia, Burkholderia, Arthrobacter, Micrococcus, Agrobacterium, Flavobacterium, Azospirillum,Azotobacter, Rhizobium, Bradyrhizobium, Mesorhizobium, Allorhizobium, Azorhizobium and Frankia can be utilised as PGPR Rhizobacteria (Table 1).

Table 1: Applications of PGPRS in Various Plant Species in Combating Different Environmental Problems

\begin{tabular}{|c|c|c|c|c|}
\hline S. No. & Plants & Types of PGPR & Effects & References \\
\hline 1. & $\begin{array}{l}\text { Prosopis juliflora } \\
\text { Lolium multiflorum }\end{array}$ & $\begin{array}{l}\text { Bacillus, } \\
\text { Staphylococcus, } \\
\text { Aerococcus }\end{array}$ & $\begin{array}{l}\text { Improved efficiency } \\
\text { of phytoremediation } \\
\text { of Chromium, } \\
\text { Copper, Lead and } \\
\text { Zinc. }\end{array}$ & Wani and Khan, 2012 \\
\hline 2. & Brassica napus & Bacillus megaterium & $\begin{array}{l}\text { Decreased Lead } \\
\text { pollution in soil and } \\
\text { increase in total yield } \\
\text { of plant. }\end{array}$ & Reichman, 2014 \\
\hline 3. & Solanumlycopersicum & $\begin{array}{l}\text { Bacillus } \\
\text { amyloliquefaciens and } \\
\text { Bacillus subtilis }\end{array}$ & $\begin{array}{l}\text { Resistance against } \\
\text { Fusarium wilt, } \\
\text { increase in lycopence } \\
\text { content and improved } \\
\text { texture of fruits }\end{array}$ & $\begin{array}{l}\text { Loganathan et al., } \\
2014\end{array}$ \\
\hline 4. & $\begin{array}{l}\text { Piper nigrum and Cucumis } \\
\text { sativus }\end{array}$ & Bacillus spp. & $\begin{array}{l}\mathrm{P} \text { and } \mathrm{K} \\
\text { solubilisation, } \\
\text { increase in fertility of } \\
\text { soil planted with } \\
\text { cucumber and pepper }\end{array}$ & Han and Lee, 2006 \\
\hline 5. & Bacillus licheniformis & Arachis hypogaea & $\begin{array}{l}\text { Increased saline stress } \\
\text { tolerace, increased } \\
\text { biomass, increased } \\
\text { root length and total } \\
\text { length of plant. }\end{array}$ & $\begin{array}{l}\text { Dweipayan Goswami } \\
\text { et al., } 2014\end{array}$ \\
\hline 6. & $\begin{array}{l}\text { Helianthus annus } \\
\text { andTriticum aestivum }\end{array}$ & $\begin{array}{l}\text { Bradyrhizobium } \\
\text { japonicum }\end{array}$ & $\begin{array}{l}\text { Excess plant biomass } \\
\text { and organic matter in } \\
\text { soil and growth } \\
\text { promotion in high } \\
\text { arsenic concentration }\end{array}$ & Yavar et al. 2014 \\
\hline
\end{tabular}

Besides bacterial species, fungal species such as Trichoderma, Aspergillus, Alternaria and Penicillium can also be used as PGPR.The PGPR promotes plant growth and development by using their own metabolism through a variety of direct or indirect mechanism such as biological nitrogen fixation, increasing the availability of nutrients in rhizosphere, enhancing the absorption of iron through siderophore production and production of phytohormones. Azotobacter species (Azotobacter chroococcum and Azotobacter vinelandii) and Azospirillum species are diazotrophs reported to fix nitrogen in on leguminous crops and other crops (Mirza et al., 2001). Inoculation of Rhizobium species is reported to show greater increase in growth and yield of the plant as compared to plants without Rhizobium sp. under field conditions (Akhtar and 
Siddiqui, 2009). Strains of Pseudomonas aeruginos, Pseudomonas putida, Burkholderia cepacia, Bacillus subtilis and Paenibacillus polymxa are reported to show solubilisation of tricalcium phosphate in soluble form due to the production of organic acids.Research conducted by different scientists reported that PGPR also facilitate uptake of mineral nutrients by solubilising organic acids and siderophore production (Dazzo et al., 2000; Biswas et al., 2000). Soil bacterial isolates ofAzotobacter vinelandii,Bacillus cereus and Bacillus megaterium are reported to facilitate siderophore production and thus promotes plant growth and disease suppression. Bacteria like Pseudomonas fluorescens, Bacillus subtilis and Paenibacillus polymyxa are also reported to synthesize hormones like IAA, cytokinins and gibberellins (Shilev, 2013; Kang et al., 2010).

\section{ROLE OF PGPR IN SUSTAINABILITY}

PGPR also used as bio-control agents providing resistance against plant pathogens such as bacteria, fungus and nematodes by synthesising a variety of antibiotic and antifungal compounds such as chitinolytic enzymes, siderophores, HCN, catalase, amphisin, phenazine, pyoluteorin, pyrrolnitrin, tensin, tropolone, cyclic lipopeptides.Oligomycin A, kanosamine, zwittermicin A, xanthobaccin and hence promoting induced systematic responses in the plants. Trichoderma harzianum is used against plant pathogens as it acts as antagonist of several soil-borne fungi such as Rhizoctonia, Pythium,Fusarium, etc (Hartmann et al., 2008). Applications of PGPRs in different plant species in combating different environmental problems is discussed in Table 1.Thus, direct association of PGPR (soil microbes) with plant's root causes mineral uptake from the soil, decompose organic matter, acquisition of nutrient and also help in plant growth promotion as well as suppression of phyto-pathogens (Nihorimbere et al., 2011, Mishra et al. 2016). Besides plant growth promotion and development, interest in PGPR has grown remarkably in terms of sustainable environment management as it plays major role in bioremediation, biodegradation, stress control, combating climate change and enhancement of soil fertility (Figure $1)$.

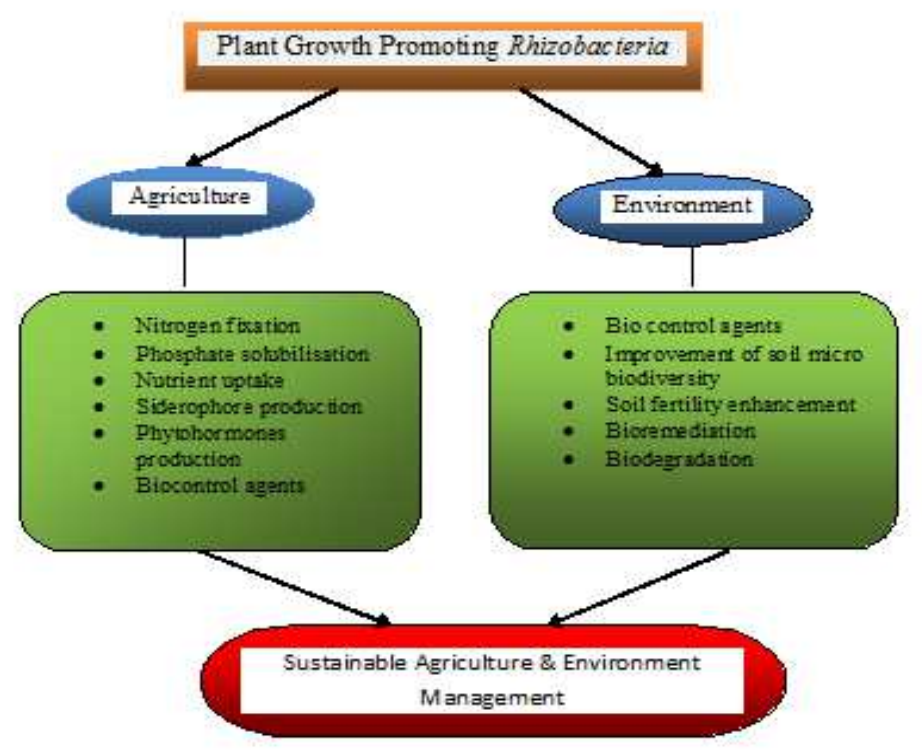

Figure 1: Multidimensional Role of PGPR on Agriculture and Environment Management

Environmental pollution due to excessive use of fossil fuels, waste generation from different anthropogenic activities, land degradation and climate change due to greenhouse gas emissions are major environmental problems so beneficial soil microbes can be incorporated for management of environmental problems. According to Zhuang et al. 
(2007) and Glick (2010), soil microbes such as Azospirillumlipoferum, Enterobacter cloacae, Pseudomonas putida and P. fluorescens are reported to remediate soil by acting on hazardous compounds such as aromatic hydrocarbons, trichloroethane, petroleum hydrocarbons. Rhizobacteria have high metal tolerance capability therefore they are used for remediating soils contaminated with metals such as mercury, cadmium, zinc, lead, copper, etc. (Reichman, 2014). Thus, Rhizoremediation serves as an effective tool in which rhizospheric microbes are incorporated for degradation of pollutants improving the status of soil as well as preventing the plants from deleterious effects of these pollutants (Kuiper et al. 2004). Soil microbes also have the capability to absorb, accumulate, transform and degrade the pollutants present in soil. They are known to synthesise enzymes such as peroxidises, phosphatases, monooxygenases, dehalogenases and nitoreductases which degrade hazardous compounds present in soil and transform them into simpler compounds such as $\mathrm{CO}_{2}$ and water to be released in the environment. For enhancing both plant and soil health, species like Pantoea agglomerans, Rhizobium spp. and Pseudomonas spp. are reported to improve soil texture and water holding capacity of soil (Tewari and Arora, 2014; Naseem and Bano, 2014).

\section{CONCLUSIONS}

Climate change is one of the major problems threatening the sustainability of environment and soil microbial diversity. Soil are reported as one of the largest sink of carbon but human intervention has led to the deterioration of this sink and release of carbon to atmosphere causing global warming. Rhizobacteria can be employed to combat climate change by applying them in stressed agroecosystems. PGPRs like Achromobacter, Azotobacter, Azospirillum, Acetobacter,Bacillus, Chryseobacterium, Flavobacterium, Enterococcus, Klebsiella, Pseudomonas, Rhizobium, Serratia and Paenibacillus are used for ameliorating drought and salinity stress conditions and shown decreased microbial respiratory carbon loss (Nie et al. 2015; Mishra et al. 2016).Bio fertilization, $\mathrm{N}_{2}$-fixation and P-solubilisation, production of antibiotics, and other plant growth promoting substances are the principal contribution of the PGPRs in the agroecosystems. All this contribution enhances the nutrient availability for both plants and soil health eliminates the dependence of agriculture on chemicals hence increases the fertility of soil and helps in combating climate change. PGPRs can have wide applications in the restoration of waste lands when inoculated, which can be later utilised as agricultural lands and can contribute to increase land under agriculture.

Thus, it can be concluded that soil microbes (PGPRs) are endowed with number of mechanisms determining its efficacy in the field of sustainable agriculture and environment management. PGPRs can be named as sustainability indicator in terms of agriculture and environment as they are used as biofertilizers, biocontrol agents and soil fertility improvers promoting agriculture in eco-friendly manner.

\section{REFERENCES}

1. Akhtar, M.S., Siddiqui, Z.A., 2009. Use of plant growth-promoting Rhizobacteria for the biocontrol of root-rot disease complex of chickpea. Aust. Plant Pathol. 38, 44-50.

2. Biswas, J.C., Ladha, J.K., Dazzo, F.B., Yani, Y.G., Rolfe, B.G., 2000. Rhizobial inoculation influences seedling vigor and yiled of rice. Agron. 92, 880-886.

3. Dazzo, F.B., Yanni Y.G., Rizk R., deBruijn F.J., Rademaker J., Squartini A., Corich V., Mateos P., Martinez-Molina F., 2000. Progress in multinational collaborative studies on the beneficial association between Rhizobium leguminosarum by trifolii and rice. In: J.K. Ladha and P.M. Reddy (Eds:), The Quest for Nitrogen Fixation in Rice.IRRI, Los Banos, Philippines, pp.167189. 
4. Glick, B.R., 2010. Using soil bacteria to facilitate Phytoremediation. Biotechnol. Adv. 2, 367-374.

5. Goswami,D., Dhandhukia P., Patel P., Thakker J.N., 2014.Screening of PGPR from saline desert of Kutch: Growth promotion in Arachis hypogea by Bacillus licheniformis A2*. Microbiol Res. 169, 66-75.

6. Han, H.S., Lee, K.D. 2006.Effect of co-inoculation with phosphate and potassium solubilizing bacteria on mineral uptake and growth of Pepper and Cucumber. Plant Soil Environ 52, 130-136.

7. Hartmann, A., Rothballer, M., Schmid, M., Hiltner, L., 2008. A pioneer in rhizosphere microbial ecology and soil bacteriology research. Plant Soil. 312, 7-14.

8. Kang, B.G., Kim, W.T., Yun, H.S., Chang, S.C., 2010. Use of plant growth-promoting rhizobacteria to control stress responses of plant roots. Plant Biotechnol Res. 4, 179-183.

9. Kuiper, I., Lagendijk, E.L., Bloemberg, G.V., Lugtenberg, B.J., 2004. Rhizoremediation: A beneficial plant-microbe interaction. Mol. Plant-Microbe Interact. 17, 6-15.

10. Loganathan, M., Garg, R., Venkataravanappa, V., Saha, S., Rai, A.B., 2014. Plant growth promoting Rhizobacteria (PGPR) induces resistance against Fusarium wilt and improves lycopene content and texture in tomato. African J Microbial Res. $8(11), 1105-1111$.

11. Mirza, M.S., Ahmad W, Latif F., Haurat J., Bally R., Normand P., Malik K.A., 2001. Isolation, partial characterization and the effect of Plant Growth-Promoting Bacteria (PGPB) on micro-popagated sugarcane in vitro. Plant Soil. 237, 47-54.

12. Mishra J., Prakash J., Arora N., 2016. Role of Beneficial Soil Microbes in Sustainable Agriculture and Environment Management. Climate change Environ Sus. 4(2), 137-14.

13. Naseem H., Bano, A., 2014. A role of plant growth-promoting rhizobacteria and their exopolysaccharide in drought tolerance of Maize. J. Plant Inter. 9, 89-94.

14. Nie, M., Bell, C., Wallenstein, M.D., Pendall, E., 2015. Increased plant productivity and decreased microbial respiratory C loss by plant growth promoting rhizobacteria under elevated CO2. Sci. Rep. 15, 9209-9212.

15. Nihorimbere, V., Ongena, M., Smargiassi, M., Thonart, P., 2011. Beneficial effect of the rhizosphere microbial community for plant growth and health. Biotechnol. Agron. Soc. Environ. 2, 327-337.

16. Reichman S.M., 2014. Probing the plant growth-promoting and heavy metal tolerance characteristics of Bradyrhizobium japonicum CB1809. Eur. J. Soil Biol. 63, 7-13.

17. Shilev, S., 2013. Soil Rhizobacteria Regulating the Uptake of Nutrients and Undesirable Elements by Plants. In: Arora NK (Ed.) Plant Microbe Symbiosis: Fundamentals and Advances. Springer, India, pp. 147-50.

18. Tewari, S., Arora, N.K., 2014. Multifunctional exopolysaccharides from Pseudomonas aeruginosa PF23 involved in plant growth stimulation, biocontrol and stress amelioration in sunflower under saline conditions. Curr Microbiol. 69, 484-94.

19. Wani, P.A., Khan, M.S., 2012. Bioremediation of lead by a plant growth promoting Rhizobium species RL9. Bacteriol. J. 2, $66-78$.

20. Yavar A, Sarmani, S, Hamzah, A., Khoo, K.S. 2014. Phytoremediation of mercury contaminated soil using Scripus mucronatus exposed by bacteria. Int. Conf. Ag. Eco. Med. Sci. 2, 6-7.

21. Zhuang, X., Chen, J., Shim, H., Bai, Z., 2007. New advances in plant growth-promoting Rhizobacteria for bioremediation. Environ Int. 33(3), 406-413. 
